\title{
Methanol, Ethanol, and Acetone Result in Non Different Concentration of Total Phenolic Content in Mangosteen (Gacinia mangostana L.) Peel
}

\author{
M. Plainsirichai ${ }^{1}$, Nipada Prasomthong ${ }^{1}$, Prapassorn Bussaman ${ }^{2} \&$ Mongkol Wongsawas ${ }^{1}$ \\ ${ }^{1}$ Department of Agricultural Technology, Faculty of Technology, Mahasarakham University, Mahasarakham, \\ Thailand \\ ${ }^{2}$ Department of Biotechnology, Faculty of Technology, Mahasarakham University, Mahasarakham, Thailand \\ Correspondence: M. Plainsirichai, Department of Agricultural Technology, Faculty of Technology, \\ Mahasarakham University, Mahasarakham 44150, Thailand. Tel: 664-375-4085. E-mail: maratreep@gmail.com
}

Received: September 23, 2014 Accepted: December 5, 2014 Online Published: January 15, 2015

doi:10.5539/jas.v7n2p131

URL: http://dx.doi.org/10.5539/jas.v7n2p131

\begin{abstract}
Peel extract of Mangosteen (Gacinia mangostana L.) can controll Aspergillus flavus, and Colletotrichum gloeosporioide since the peel contains high total phenolic content. However, different solvents might result in a different extraction yield of total phenolics. This research studied the effect of 4 solvents, acetone, ethanol, methanol, and water on total phenolic content in the fresh and dry peel of mangosteen. Folin-Ciocalteu method was used for total phenolic content analysis. The result demonstrated that mangosteen peel extracted with methanol, ethanol, and acetone contained non significant difference of total phenolic contents in dry mangosteen peel. Extraction of the peel with water resulted in less total phenolic content than other solvents in both fresh and dry magosteen peel. In conclusion, to obtain high total phenolic content, methanol, ethanol, and acetone, should be used for the extraction of total phenolic content from mangosteen peel.
\end{abstract}

Keywords: mangosteen, Gacinia mangostana L., peel, ethanol, methanol, acetone, water

\section{Introduction}

Mangosteen (Gacinia mangostana L.) is an important fruit of Thailand. Its peel contains antioxidants particularly phenolic compounds such as xanthonse, condensed tannins and anthocyanins. Phenolic represents a striking example of metabolic plasticity enabling plants to adapt to changing biotic and provide to plant products colour, taste, technological properties and putative health promoting benefits (Boudet, 2007). Many studies revealed the phenolic can inhibit microorganism growth (Pothitirat et al., 2009). Study of Yenjit et al. (2003) demonstrated that mangosteen's peel controlled Aspergillus flavus, and Colletotrichum gloeosporioide, fungi-pathogen in mango. Mangosteen peel extract inhibited Aspergillus spp. which caused seed rot in mungbean (Vigna radiata) (Kittipat et al., 2008). It also inhibited Ralstonia solanacearum, pathogenic bacteria, which caused wilt disease in tomato (Sasitorn \& Supot, 2005).

Extraction of phenolic from plant material with solvent gives reasonable recovery. However, extraction of mangosteen peel with different solvents might result in a different concentration of total phenolic contents. This research investigated the effect of solvents on total phenolic content in mangosteen peel. We hypothesized that extraction of the peel with methanol would result in high total phenolic content than other solvents in both fresh and dry magosteen peel.

\section{Method}

The mangosteen fruit were obtained from local market. They were soaked in $1 \% \mathrm{NaClO}_{2}$ for 30 mins. The mangosteen fruit was then peeled and washed with distillated water. They were dried in a hot air oven at $40{ }^{\circ} \mathrm{C}$ for $24 \mathrm{hrs}$. Then the samples were extracted with 4 solvents, acetone, ethanol, methanol, and water, at 1:7 ratio by weight, for $1 \mathrm{hr}$. The solution was filtered with a muslin cloth before centrifuging at $10,000 \mathrm{rpm} / \mathrm{min}$ for 20 mins at $4{ }^{\circ} \mathrm{C}$ and then filtering with filter paper no. 1. The solution was then taken for total phenolic analysis following Folin-Ciocalteu method which was optimized from Singleton et al. (1999). The solution was measured with spectrophotometer at $765 \mathrm{~nm}$. The reading values of gallic standard at 50, 100, 300, 500, 700 and 1,500 
ppm were ploted in a graph. Analysis of variance and LSD (Least Significant Difference) at 95\% were used to compare difference among treatments.

\section{Results}

The results demonstrated that total phenolic content in fresh mangosteen peel extracted with methanol, ethanol, acetone, and water was 27,138, 19,392, 19,016 and 7,504 mgGAE/100 gDW respectively (Figure 1). The peel extracted with methanol, ethanol, and acetone contained non significant difference of total phenolic content in dry mangosteen peel (Figure 1).

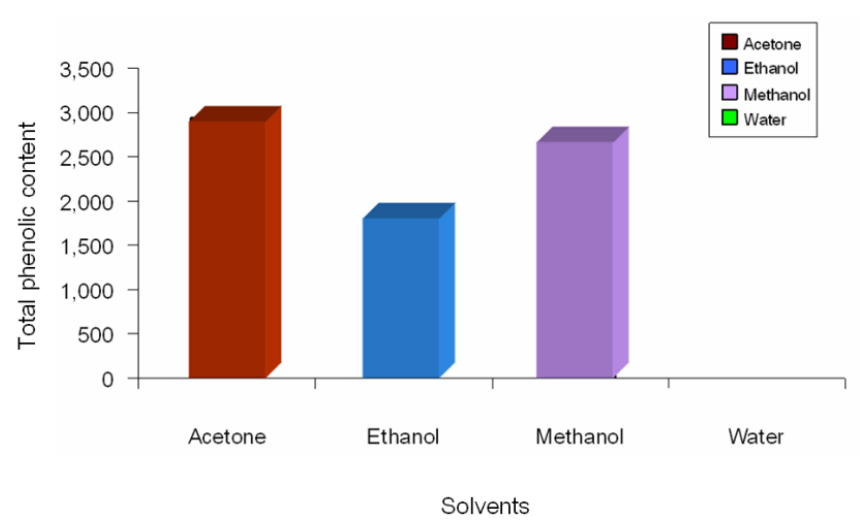

Figure 1. Effect of differenct solvents on total phenolic content in fresh mangosteen peel (mgGAE/100 gDW)

\section{Discussion}

Methanol, ethanol, and acetone result in non different concentration of total phenolic content in mangosteen peel. The result of this study was in contrast with the study of Mohsen and Animar (2009) which demonstrated that corn tasse extracted with ethanol and methanol had a higher concentration of total phenolic content than that extracted with acetone, methanol, hexene, chloropform, buthanol, phetholeme, and water. Methanol, ethanol, and acetone are the good solvents on the extraction of mangosteen peel as they are polar solvents. Extracting the peel with water resulted in less total phenolic content than other solvents.

Study of Urusa \& Mingmuang revealed that the total phenolic content in dry mangosteen peel extracted with acetone by Folin-Ciocalteu method contained total phenolic 2,930.43 mgGAE/100 gDW. Zadernowski et al. (2009) explored total phenolic analysed with Gas chromatography-mass spectrometry (GC-MS) and revealed that mangosteen peel contained total phenolic 5,027.7 $\pm 188.0 \mathrm{mg} / \mathrm{kgDW}$. Ponstron et al. (2008) demonstrated that total phenolic in freeze dry mangosteen peel was $215.1 \pm 25.1 \mathrm{mgGAE} / 100 \mathrm{gDW}$. Khonkarn et al. (2010) demonstrated that young peel of mangosteen contained higher phenolic content than the mature peel. Study of Dangcham et al. (2008) revealed that red-brown and red-purple mangosteen peel contained total phenolic $10,000.73 \mathrm{mg} / \mathrm{kgFW}$ and $11,000.32 \mathrm{~g} / \mathrm{kgFW}$ respectively when they were extracted with $65 \%$ ethanol and $0.5 \%$ sodium metabisulfite. This indicates the variation in the degree of maturity harvest, cultivation, preharvest environmental conditions, and postharvest handling, might have an affect on total phenolic in mangosteen peel. 


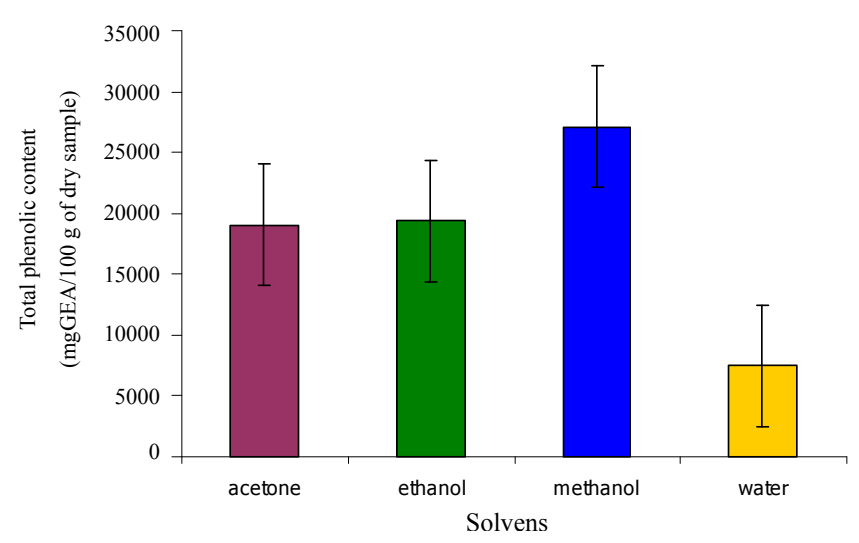

Figure 2. Effect of differenct solvents on total phenolic content in dry mangosteen peel (mgGAE/100 gDW) Different lettrs indicating significant differences by LSD (Least significnat rang test) $(\mathrm{LSD}=9.121)(\mathrm{P} \leq 0.05)$.

\section{Acknowledgements}

We would like to thank the National Research Council of Thailand and Mahasarakham University, Thailand for financial and instrument support.

\section{References}

Arusa, C., \& Mingmuang, A. (2007). Anthocyanin and total phenolic content of mangosteen and its juices. Srinakharinwirot Science Journal, 23, 68-78.

Boudet, A. M. (2007). Evolution and current status of research in phenolic compounds. Phytochemistry, 68, 2722-2735. http://dx.doi.org/10.1016/j.phytochem.2007.06.012

Dangcham, S., Bowen, J., Ferguson, I. B., \& Ketsa, S. (2008). Effect of temperature and low oxygen on pericarp hardening of mangosteen fruit stored at low temperature. Postharvest Biology and Technology, 50, 37-44. http://dx.doi.org/10.1016/j.postharvbio.2008.02.005

Khonkarn, R., Okonogi, S., Ampasavate, C., \& Anuchapreeda, S. (2010). Investigation of fruit peel extracts as sources for compounds with antioxidant and antiproliferative activities against human cell lines. Food Chemistry Toxicology, 48, 2122-2129. http://dx.doi.org/10.1016/j.fct.2010.05.014

Kittipat, S., Rangjaroen, C., \& Nachapong, M. (2008). Efficiency of mangosteen's peel crude extact for conrolling Aspergillus spp. 34th Congress on Science and Technology of Thailand, Queen sirikit national convention center, Bangkok.

Li, B. B., Smith, B., \& Hossain, Md. M. (2006). Extraction of phenolics from citrus peels I. Solvent extraction $\begin{array}{llll}\text { method. Separation } \quad \text { and Purification } & \text { 182-188. }\end{array}$ http://dx.doi.org/10.1016/j.seppur.2005.07.019

Mohsen, S. M., \& Ammar, A. S. M. (2009). Total phenolic contents and antioxidant activity of corn tassel extracts. Food Chemistry, 112, 595-598. http://dx.doi.org/10.1016/j.foodchem.2008.06.014

Pothitirat, W., Chomnawang, M. T., Supabphol, R., \& Gritsanapan, W. (2009). Comparison of bioactive compounds content, free radical scavenging and anti-acne inducing bacteria activities of extracts from the mangosteen fruit rind at two stages of maturity. Fitoterapia, 80, 442-447. http://dx.doi.org/10.1016/j.fitote.2009.06.005

Pongsatone, L., Rechtanapun, C., \& Chantanawarangoon, S. (2008). Total phenolics, radical scavenging capacity and antimicrobial property of fruit peels (pp. 554-561). The proceeding of 45th Kasetsart Uiversity annual conference, Bangkok.

Sasitorn, V., \& Supot, S. (2005). Efficacy of Medicinal Plant Crude Extracts on Growth Inhibition of Ralstonia solanacearum. Kamphaengsaen Acad., 3, 11-27.

Singleton, V. L., Orthofer, R., \& Lamuela-Raventós, R. M. (1999). Analysis of total phenols and other oxidation substrates and antioxidants by means of folin-ciocalteu reagent. Methods in Enzymology, 299, 152-178. http://dx.doi.org/10.1016/S0076-6879(99)99017-1 
Zadernowski, R., Czaplicki, S., \& Naczk, M. (2009). Phenolic acid profiles of mangosteen fruits (Garcinia mangostana). Food Chemistry, 112, 685-689. http://dx.doi.org/10.1016/j.foodchem.2008.06.030

Yenjit, P., Issarakraisila, M., Intana, W., Sattasalalchai, S., Suwanno, T., \& Chantrapromm, K. (2008). Efficacy of extract substances from the pericarp of Garcinia mangostana to control major diseases of tropical fruits in laboratory. Acta Horticulture, 1, 339-343.

\section{Copyrights}

Copyright for this article is retained by the author(s), with first publication rights granted to the journal.

This is an open-access article distributed under the terms and conditions of the Creative Commons Attribution license (http://creativecommons.org/licenses/by/3.0/). 